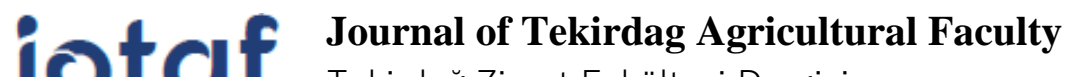

\section{Buğdayın Verimi ve Kalite Parametrelerinin Toprağın Elektriksel İletkenliği ile İlişkisinin Belirlenmesi}

Determination of Yield and Quality Parameters of Wheat Related with Electrical Conductivity of Soil

\section{Uğur YEGÜL ${ }^{1 *}$, Maksut Barış EMINOĞLU1 ${ }^{1}$, Ufuk TÜRKER ${ }^{1}$}

\section{$\ddot{O} \mathbf{z}$}

Bu çalışmanın amacı, toprağın elektriksel iletkenliğini kullanarak buğday bitkisinde ürün verimi ve protein içeriği değişimini belirlemektir. Çalışma sonucunda bu parametreler arasında önemli ilişkiler tespit edilmiştir. Araştırmada kullanılan bütün çeşitler için toprağın elektriksel iletkenlik değerli ile buğday bitkisine ait verim ve protein içeriği değerleri arasında doğrusal ilişkiler bulunmuştur. Elde edilen sonuçlara göre elektriksel iletkenlik değerlerinin artması ile birlikte verim değerleri düşmekte protein içeri ise artmaktadır. Araştırma sonucu arazinin elektriksel iletkenlik değerleri ile verim değerleri arasındaki ilişkiler $\left(\mathrm{R}^{2}\right)$ sırasıyla Bezostaja-1 çeşidi için 0,81 , Gün-91 çeşidi için 0,81, Sagittario çeşidi için 0,77, Altıntaş- 95 çeşidi için 0,73 ve Gönen- 98 çeşidi için 0,88 olarak bulunmuştur. Arazinin elektriksel iletkenlik değerleri ile protein içerikleri arasındaki ilişkiler $\left(\mathrm{R}^{2}\right)$ ise sırasıyla Bezostaja-1 çeşidi için 0,83 , Gün-91 çeşidi için 0,86 , Sagittario çeşidi için 0,85 , Altıntaş- 95 çeşidi için 0,85 ve Gönen-98 çeşidi için 0,88 olarak bulunmuştur.

Anahtar Kelimeler: Elektriksel iletkenlik, EM38, buğday, verim, protein

\begin{abstract}
The aim of this study was to determine the spatial variation in yield and protein content of wheat plant by utilizing the electrical conductivity of the soil. As a result of this study, significant relationships were determined. For all of the varieties used in the research, a linear relationship were found between electrical conductivity values of the soil with the yield values as well as the protein contents. According to the results, with the increase of electrical conductivity values, yield values decreases and the protein content increases. As a result of the research, the relations between the electrical conductivity values of the soil and the yield values were determined as $R^{2}=0,81$ for bezostaja-1, $R^{2}=0,81$ for Gün-91 variety, $R^{2}=0,77$ for Sagittario and $R^{2}=0,73$ for Altıntaş-95 as well as $R^{2}$ $=0,88$ for Gönen-98 varieties respectively. The relationships between the electrical conductivity values of the soil and the protein contents were determined as $R^{2}=0,83$ for Bezostaja- 1 variety, $R^{2}=0,86$ for the Gün-91 variety, $\mathrm{R}^{2}=0,85$ for the Sagittario variety, $\mathrm{R}^{2}=0,85$ for the Altıntaş- 95 variety and it was found as $\mathrm{R}^{2}=0,88$ for Gönen98 variety respectively.
\end{abstract}

Keywords: Electrical conductivity, EM38, wheat, yield, protein

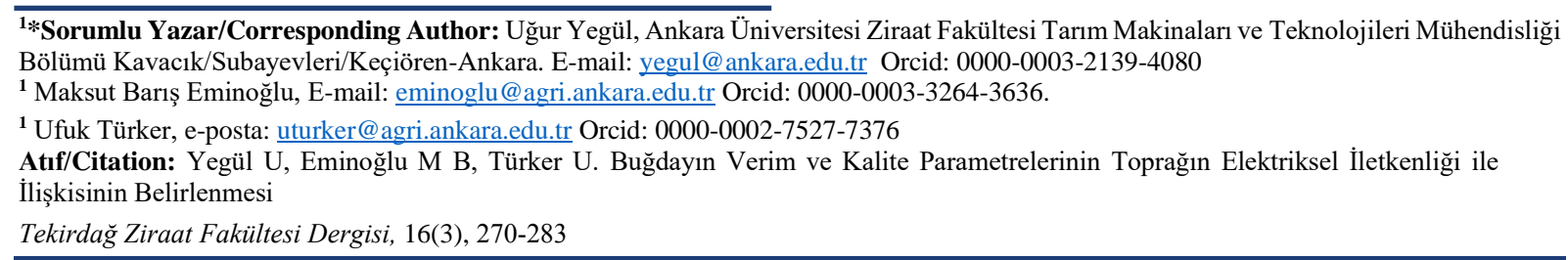




\section{Extended Summary}

Farmers can recognize their field with crops with the help of proximity sensor used in this study. With the developing technology, precision agriculture has been a rapidly developing area and necessity for new researches. Reducing the use of inputs not only for fertilizers and seeds etc. but also for equipment used. The aim of this study was to measure the electrical conductivity in the field quickly and then to evaluate the relations of plants reflection index with other parameters such as yield and quality.

This research was carried out in Haymana Research Farm of Ankara University. Five different varieties of wheat were used in the study. These varieties were; bezostaja-1, gün-91, sagittario, Altıntaş-95 and Gönen-98. Field experiments were carried out in a randomized block design with four replications at Haymana province, Ankara, Turkey in two consecutive years between 2016 and 2017. Before planting, DAP (diammonium phosphate) was used as preplant fertilizer, which was widely used by the farmer in the region, and pre-planting operations, maintenance etc. were carried out with the help of farm workers. As fertilizing dose $200 \mathrm{~kg} \mathrm{ha}^{-1}$ DAP was applied in the 30th period according to the Zadoks scale (Zadoks ve ark. 1974). The yield was calculated after the harvestthreshing process with parcel harvester. The protein ratio of wheat was determined by the of Perten IM8800 (Perten Instruments) protein measurement unit. Electrical conductivity values of the field were obtained with EM38 (Geonics Limited). The EM38 sensor have been mainly used in the mining industry. however, in the following years, these sensors were used in agriculture and their applications in agriculture were first used in soil moisture and salinity studies.

EM38 sensors work with a GPS and a handheld computer. The readings of the EM38 sensor were used by nonmetallic materials or on the shoulder as they affect metal objects. These readings were combined with data from GPS and recorded in one second on the handheld computer. Field was scanned with EM38 sensor with shoulder strap, $20 \mathrm{~cm}$ in height from soil surfaces. After the data were transferred to the desktop computer, the conversion was performed from point data to map data and evaluated statistically.

According to the results obtained in our studies, there is an inverse relationship between the electrical conductivity and yield values. With this study, it was determined that the higher the yield values of the plots lower the electrical conductivity values of the soil. The correlation between protein content of wheat and electrical conductivity values did exist. It was found that the protein content of the wheat increased due to the increase of the electrical conductivity values of the soil.

As a result of the research, the relations between the electrical conductivity values of the soil and the yield values were determined as $R^{2}=0,8152$ for bezostaja- $1, R^{2}=0,8115$ for Gün-91 variety, $R^{2}=0,7775$ for Sagittario and $\mathrm{R}^{2}=0,7380$ for Altıntaş-95 as well as $\mathrm{R}^{2}=0,8852$ for Gönen-98 varieties respectively. The relationships between the electrical conductivity values of the soil and the protein contents were determined as $R^{2}=0,8375$ for Bezostaja-1 variety, $R^{2}=0,8637$ for the Gün-91 variety, $R^{2}=0,8561$ for the Sagittario variety, $R^{2}=0,8598$ for the Altıntaş-95 variety and it was found as $\mathrm{R}^{2}=0,8852$ for Gönen-98 variety respectively.

Today, the use of technology in agriculture is at the highest level. Besides, the necessity to use technology to produce more with efficiently is revealed. Numerous sensors that detect growth indexes of plants are used today. The yield values and some quality parameters of the plants can be controlled and improved by using proximate electrical conductivity measurement devices. 

ayrılmaktadır. Toprağa temaslı olarak çalışan sensörler ve toprağa temassız olarak çalışan sensörlerdir. Bu araştırmada toprağa temas etmeden çalışan toprak elektriksel iletkenlik sensörü EM38 kullanılmıştır. Teknolojinin hızla ilerlemesi ve kullanımının yaygınlaşması tarım sektöründe de olumlu sonuçlar vermektedir. Artık günümüzde çiftçi sadece traktör ve gerekli birkaç ekipman dışında hassas tarım uygulamalarında kullanılan sensörleri benimsemeye ve kullanmaya başlamıştır. Bu gelişme, ürünlerin yetiştirilmesi için gerekli girdileri minimize etmekte ve çıktı yani verimi ise optimize etmektedir.

Yüksek oranlarda su kullanılarak hazırlanan çamurlardan elde edilen süzüklerde elektriksel iletkenliğin belirlenmesi, saturasyon çamuru yöntemine göre daha kolay olmakla birlikle anlamlı toprak özellikleriyle daha az ilişkili olması, peptizasyon, hidroliz, katyon değişimi ve mineral madde çözümünden kaynaklanan hatalara daha açık olması gibi sakıncalı yönleri bulunmaktadır (Rhoades ve ark. 1999, Corwin ve Lesch 2005).

Gübrelerden kaynaklanan tuzluluk da diğer toksik iyonlardan ( $\mathrm{Na}, \mathrm{Cl}$ vb.) kaynaklanan tuzluluk gibi iyonik ve ozmotik etki yaratarak bitki gelişimini olumsuz etkilemektedir (Eraslan ve ark. 2008).

Literatür çalışmalarında, toprak tuzluluğu, toprak sıkışıklığı ve dolayısıyla toprağın elektriksel iletkenliği ile yapraklardaki mineral madde içeriği üzerine etkisi ile ilgili bir çok çalışma yapıldığ görülmüştür (Amor ve ark. 2001, Fernandez-Garcia ve ark. 2004, Tuna ve ark. 2007, Bilgin ve Yildiz 2008, Eraslan ve ark. 2008, Zhu ve ark. 2008, Giuffrida ve ark. 2009, Mohammed ve ark. 2009, Huang ve ark. 2010, Eraslan ve ark. 2012) ancak, meyvelerin mineral madde içeriği ile ilgili birkaç çalışmaya ulaşılmıştır. Bu çalışmaların çoğunda meyvedeki mineral madde içeriği üzerine çeşitlerin, yetiştirme ortamlarının veya yetiştirme yöntemlerinin etkileri incelenmiştir (Premuzic ve ark. 1998, Gunderson ve ark. 2001, Gui-Guerrero 2009, Rebolloso-Fuentes 2009).

Çalışmada kullanılan sensör gibi kullanımı kolay olan sensörler yardımıyla çiftçi arazisini daha iyi tanımakta ve alana özgü uygulama yapabilmekte ve elde edeceği ürün hakkında tahmin yürütebilmektedir. Gelişen teknoloji ile birlikte hassas tarım hızla gelişen bir alan olmuş ve sürekli yeni araştırmalara ihtiyaç duymaktadır. Bu ihtiyaçlar doğrultusunda girdilerin kullanımının azaltılması konusu sadece gübre ve tohum vs. gibi girdileri değil aynı zamanda kullanılan ekipmanları da kapsamaktadır. Bu çalışmanın amacı elektriksel iletkenliğin arazide hızlı bir şekilde ölçülüp daha sonra kısa sürede değerlendirilerek bitkilerin başta verim olmak üzere kalite gibi diğer parametrelerle olan ilişkilerini araştırmaktır.

\section{Materyal ve Metot}

Bu Araştırma Ankara Üniversitesine bağlı Haymana Araştırma Çiftliğinde toplam 2 yıllık bir sürede gerçekleştirilmiştir. Araştırmada 5 farklı buğday çeşidi tesadüfi deneme blokları deneme deseninde ve 4 tekerrürlü, $15 \mathrm{~cm}$ sıra aralığında 6 sıraya, $10 \mathrm{~m}$ parsel uzunluğunda olacak şekilde ve $20 \mathrm{~kg} \mathrm{ha}^{-1}$ üst gübre dozu kullanılarak toplamda 20 parsele ekim, bakım ve hasat işlemi yapılarak gerçekleştirilmiştir. Ekimden önce çiftçinin yörede yaygın olarak kullandığı taban gübresi DAP kullanılmış ve ekim öncesi işlemler, bakım, ilaçlama ve üst gübre dozunun uygulanması çiftlik çalışanları yardımı ile gerçekleştirilmiştir. Üst gübre buğday sapa kalkmadan önceki dönemde, Zadoks skalasına göre 30. dönemde uygulanmıştır (Zadoks ve ark. 1974). 
JOTAF/ Journal of Tekirdag Agricultural Faculty, 2019, 16(3)

Çizelge 1. Deneme deseni (Tesadüfi deneme blokları; T1: bezostaja-1, T2: gün-91, T3: sagittario, T4: altıntaş-95 ve T5: gönen-98)

Table 1. Field experiment design (Randomized block design; T1: bezostaja-1, T2: gün-91, T3: sagittario,

T4: altıntaş-95 ve T5: gönen-98)

\begin{tabular}{|c|c|c|c|c|}
\hline T1 & T4 & T2 & T5 & T3 \\
\hline T4 & T2 & T1 & T3 & T5 \\
\hline T5 & T1 & T3 & T2 & T4 \\
\hline T2 & T3 & T5 & T1 & T4 \\
\hline
\end{tabular}

Araştırmada kullanılan 5 farklı buğday türü; bezostaja-1, gün-91, sagittario, altıntaş-95 ve gönen-98 çeşitleridir. Bezostaja-1 çeşidinin genel görünüşü; kısa boylu, sağlam yapılı, gri yeşil renkli ve tüysüz yapraklara sahip olmasıdır. Taneleri kırmızı-sert ve camsı özellikte olup bin tane ağırlığı yaklaşık 44 gramdır. Bir diğer çeşit olan Gün-91' in genel görünüşü itibariyle yaklaş1k 100 cm uzunluğunda yeşil ve tüysüzdür. Taneleri kırmızı küçük ve camsı yapıdadır. Diğer bir çeşit ise Sagittario, sağlam yapılı ve yatmaya dayanıklıdır. Taneleri kırmızı serttir.

Bin tane ağırlığı 40-44 gr arasındadır. Altıntaş-95 çeşidi ise yaklaşık $120 \mathrm{~cm}$ boyundadır. Taneleri camsı yapıdadır ve kurağa dayanıklıdır ve makarnalık bir çeşittir. Gönen-98 ise orta boylu, yuvarlak sert ve beyaz tanelidir. Taneleri camsı yapıdadır. Bin tane ağırlığı yaklaşık olarak 32 gr'dır..

Arazinin elektriksel iletkenlik değerleri ise elektromanyetik dalga yayarak çalışan uzaktan algılama sensörü (EM38) ile elde edilmiştir (Şekil 1). Çalışmada kullanılan EM38 sensörü esasen maden endüstrisinde kullanılmaktadır. Ancak daha sonraki yıllarda bu sensörler tarımda da kullanılmaya başlanmış bu cihazın tarımdaki uygulamaları ilk olarak toprak nemi ve tuzluluk çalışmalarında kullanılmasıyla olmuştur.

EM38 sensörleri bir GPS konum bilgileri alıcısı (Magellan SporTrak, Geomaticsgroup) ve bir el bilgisayarı (Allegro CX-Juniper Systems, Inc.) yardımı ile çalışmaktadır. EM38 sensörünün okumaları metal cisimlerden etkilediği için metal olmayan malzemeler yardımı ile ya da el ile omuzda taşınarak kullanılması gereklidir. Toprağa gönderilen sarmal şeklindeki elektromanyetik sinyaller tekrar okunarak toprağın yapısına bağlı olarak elektriksel iletkenlik değerleri bulunur (Şekil 2). Okunan bu değerler GPS konum bilgileri alıcısından gelen veriler ile birleştirilerek aynı zamanda birbirine bağlı olan el bilgisayarında kaydedilmektedir (Şekil 3).

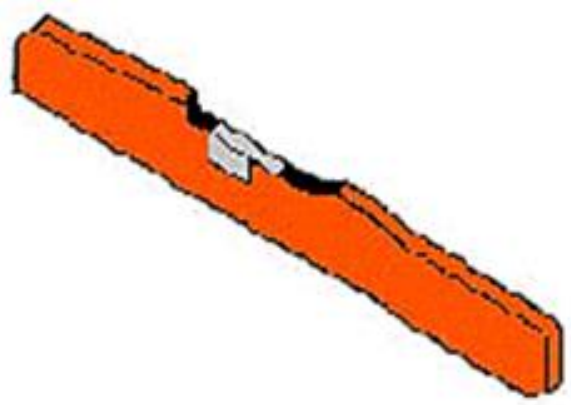

EM-38

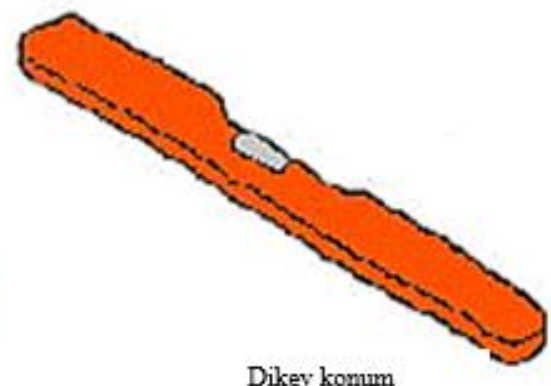

Dikey konum

Şekil 1. EM38 sensörünün kullanım şekilleri (anonim, 2019a)

Figure 1. Different types of EM38 sensor usage (anonymous, 2019a) 


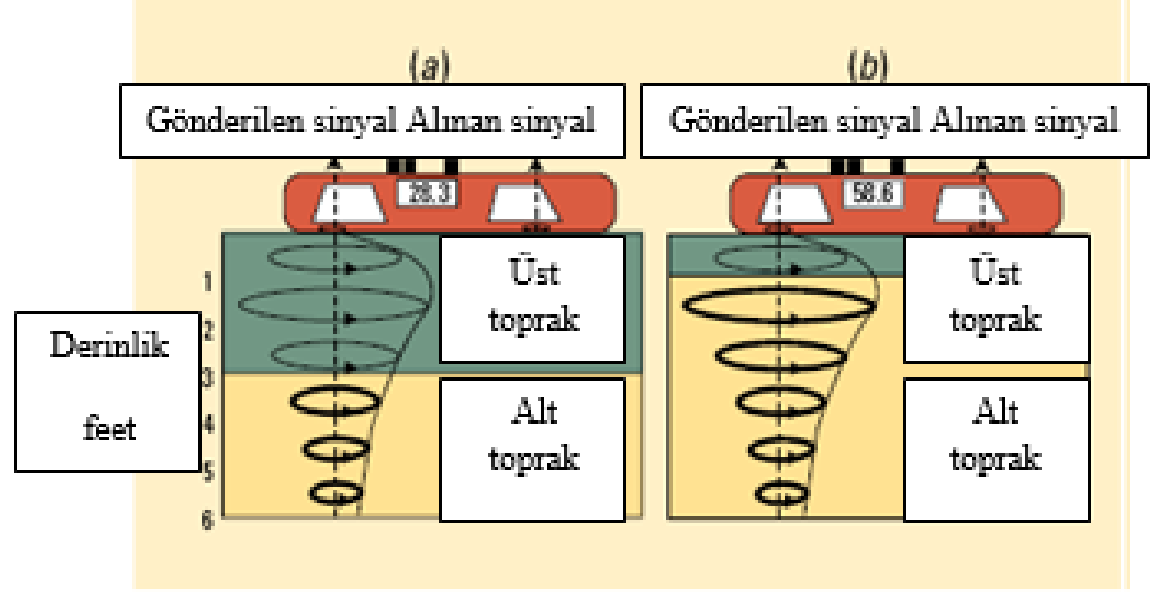

Şekil 2. EM38 sensörünün çalışma prensibi (anonim, 2019a)

Figure 2. Working principle of EM38 sensor (anonymous, 2019a)

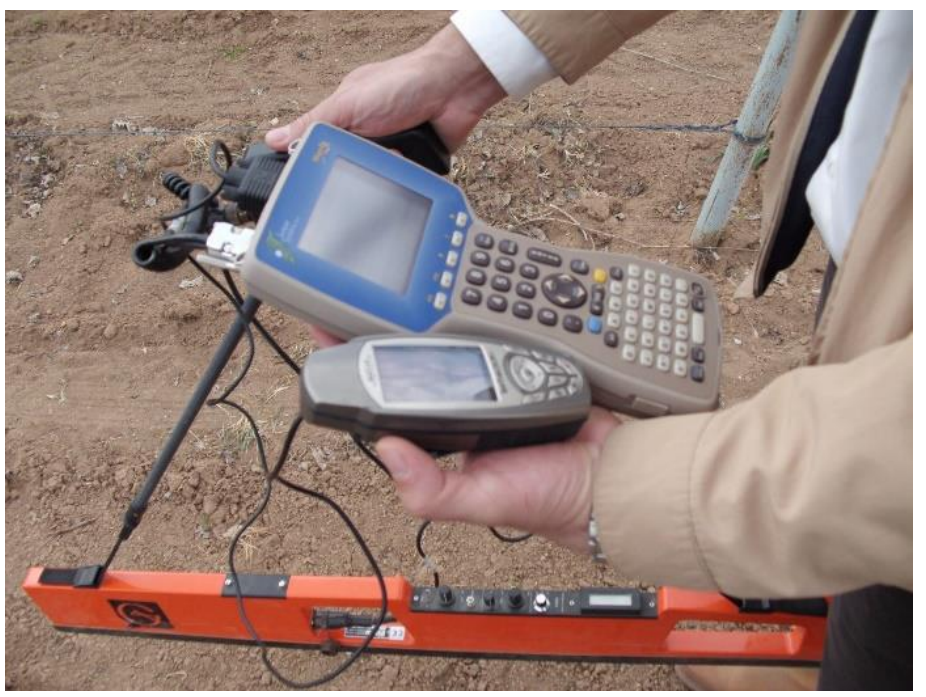

Şekil 3. EM38 sensörü, el bilgisayarı ve GPS

Figure 3. EM38, handheld computer, and GPS

EM38 sensörleri yaklaşık 1 metre uzunluğundadır. Metal nesnelerden uzak, genellikle ahşap bir taşıyıcı çatı üzerine veya omuza yerleştirilerek çekilmektedir. Bu çalışmada omuzda çekilerek kullanılmıştır. Sensör bir GPS verileri alıcısı ve bir el bilgisayarının birbirlerine bağlanması ile kullanılmaktadır. Sensörün İki farklı kulanım şekli bulunmaktadır. Bunlardan birincisi yatay moddur. Bu modda 1,5 metre derinliğe kadar ölçüm yapılabilmektedir. Diğeri ise dikey moddur. Bu moda ise 0,75 metre derinliğe kadar ölçüm yapılabilmektedir. Bu çalışmada yatay modda ölçümler gerçekleştirilmiştir. Sensör toprağa temas etmeden kullanılmaktadır. $1 \mathrm{ile} 10 \mathrm{~Hz}$ aralığında, 1 Hz'lik ayarlanabilir kademelerle veri alınmış ve alınan bu veriler GPS cihazından gelen konum bilgileri ile birleştirilerek kaydedilmiştir.

El bilgisayarı, EM38 ve GPS ile birlikte kullanılmıştır. Cihaz barındırdığı mevcut yazılımları ile diğer sensörler ve GPS alıcılarıyla rahatlıkla kullanılabilmektedir. 


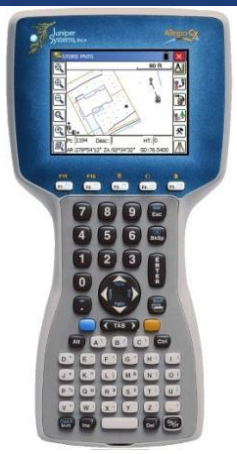

(a)

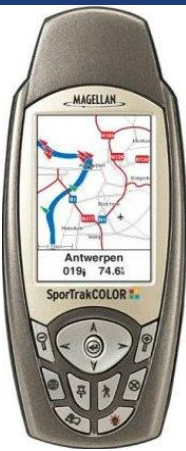

(b)

Şekil 4. (a) Allegro CX el tipi arazi bilgisayarı (Anonymous, 2019b), (b) Magellan SporTrak Color GPS (Anonymous, 2019c)

Figure 4. (a) Allegro CX handheld computer (Anonymous, 2019b), (b) Magellan SporTrak Color GPS (Anonymous, 2019c)

Çalışmada kullanılan GPS cihazı araştırmada kullanılan EM38 sensörü ve el bilgisayarına bağlanarak EM38'in okuduğu verilere koordinat bilgilerini ekleyerek el bilgisayarına kaydedilmesini sağlamıştır.

EM38 sensörünün el bilgisayarına gerekli bağlantıları sağlandıktan sonra GPS cihazı da el bilgisayarına bağlanmıştır. Gerekli kontroller yapıldıktan ve sistem hazır hale getirildikten sonra EM38 sensörü omuz askısı ile yerden $20 \mathrm{~cm}$ yükseklikte ve saniyede bir veri alınarak şekilde okuma yapılmıştır.

Alınan veriler masaüstü bilgisayara aktarıldıktan sonra dönüşüm işlemi gerçekleştirilerek düzenlenmiş ve istatistiksel olarak değerlendirilmiştir.

Tane verimi parsel biçerdöveri ile yapılan hasat-harman işleminden sonra taneler tartılarak veriler dekara çevrilmiş ve kg olarak hesaplanmıştır. Buğdayın protein oranı Perten IM8800 marka cihazla her parselden elde edilen buğdaylardan 500 gr örnek alarak tespit edilmiştir.

Protein analizi için kullanılan Perten marka cihaz, tarlada, siloda veya tahıl işleme alanlarında rahatlıkla kullanılabilmek üzere tasarlanmıştır (Şekil 5). GPS ile donatılmış bu cihaz protein haritaları hareket halinde de oluşturabilmektedir.

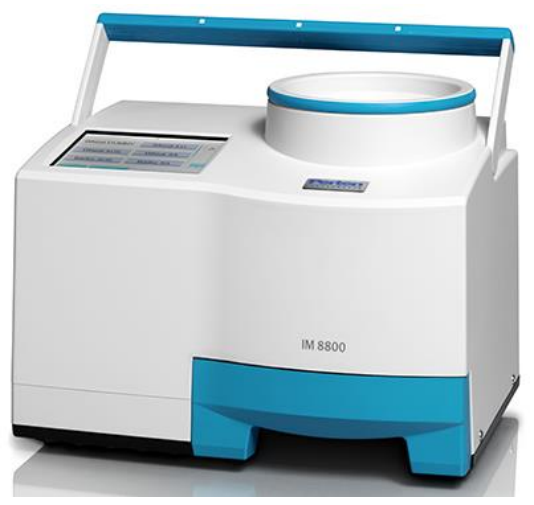

Şekil 5. Perten marka Inframatic 8800 tahıl analiz cihazı (Anonymous, 2019d)

Figure 5. Perten Inframatic 8800 NIR Grain Analyzer (Anonim, 2019d) 
Şekil 6'dan 15'e kadar 5 farklı çeşit ile gerçekleştirilen arazinin elektriksel iletkenlik değerleri ile verim ve protein içeriği arasındaki ilişkiler grafik olarak verilmiştir. Şekil 6 ve 7, bezostaja-1 çeşidi için sırasıyla elektriksel iletkenlik ile verim ve protein içeriği değerleri arasındaki ilişkileri göstermektedir. Şekil 8 ve 9, Gün-91 çeşidi için, Şekil 10 ve 11, Sagittari, Şekil 12 ve 13 Altıntaş-95 çeşidi için ve Şekil 14 ve 15 ise Gönen-98 çeşidi için sırasıyla elektriksel iletkenlik ile verim ve protein içeriği değerleri arasındaki ilişkileri vermektedir. Grafiklerden de anlaşılabileceği gibi arazinin elektriksel iletkenlik değerleri ile buğdayın verim değerleri ve protein içeriği arasında doğrusal bir ilişki söz konusudur. Elektriksel iletkenlik değerlerinin artmasına bağlı olarak verim değerlerinde bir düşüş protein içeriğinde ise bir artış söz konusu olmaktadır. Çizelge 2 ve 3 'te ise çeşitler üzerinde yapılan araştırmada farklı parsellerde gerçekleşen tekerrürlerin sonuçları regresyon eşitlikleriyle birlikte verilmiştir.

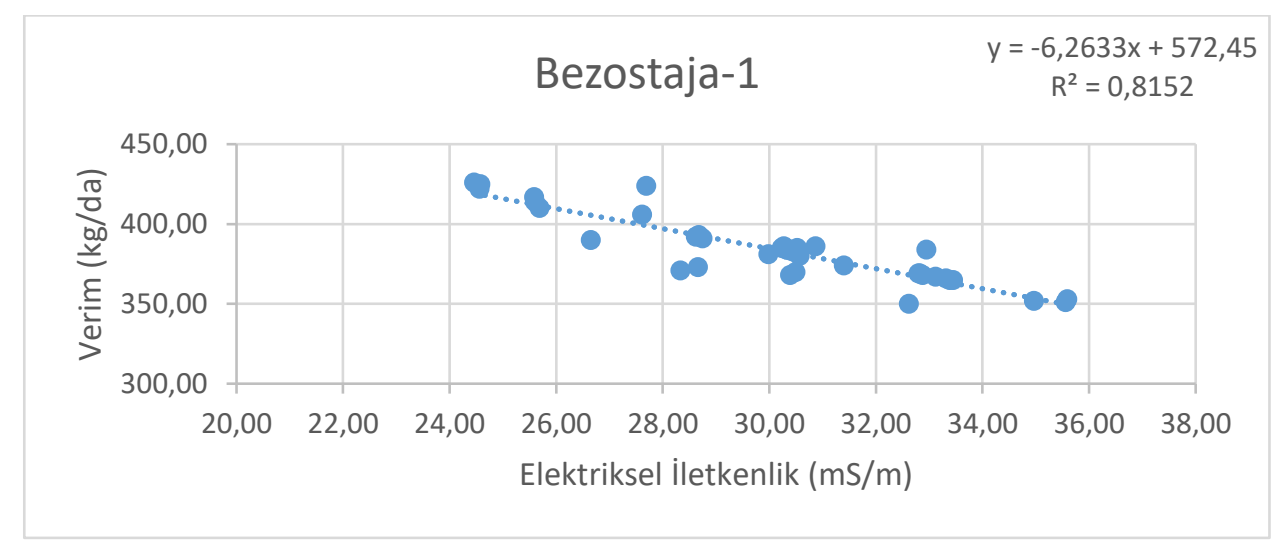

Şekil 6. Bezostaja-1 çeşidinin elektriksel iletkenlik ile verim değerleri arasındaki ilişki

Figure 6. The relationship between electrical conductivity and yield values of Bezostaja-1 variety

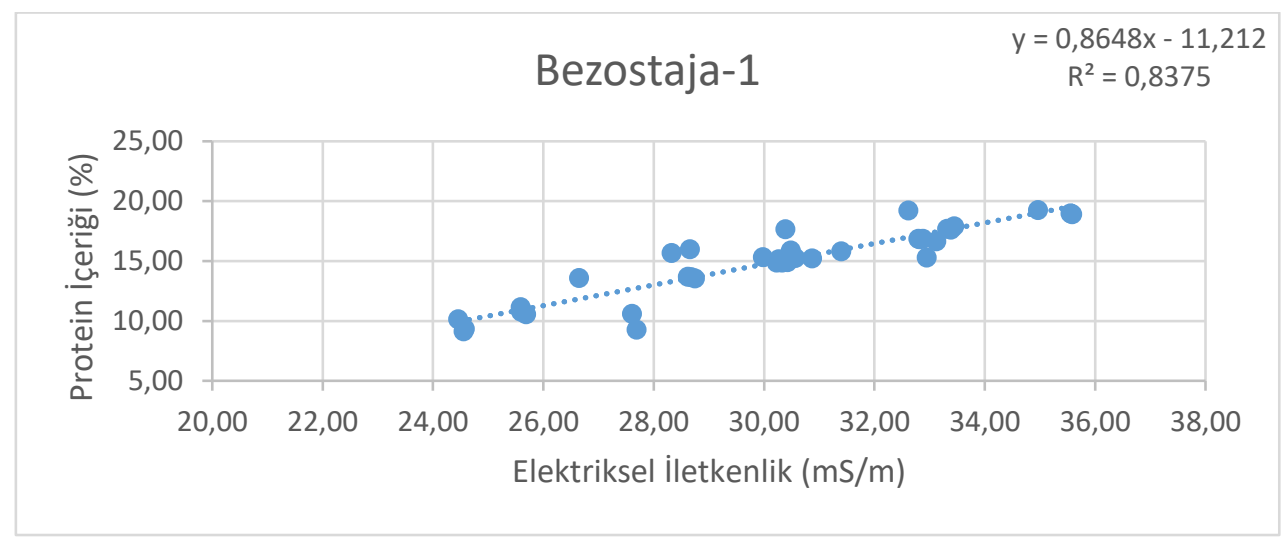

Şekil 7. Bezostaja-1 çeşidinin elektriksel iletkenlik değerleri ile protein içeriği arasındaki ilişki

Figure 7. The relationship between electrical conductivity values and protein content of Bezostaja-1 variety 
Gün-91

$y=-6,2577 x+578,05$

$$
\mathrm{R}^{2}=0,8115
$$

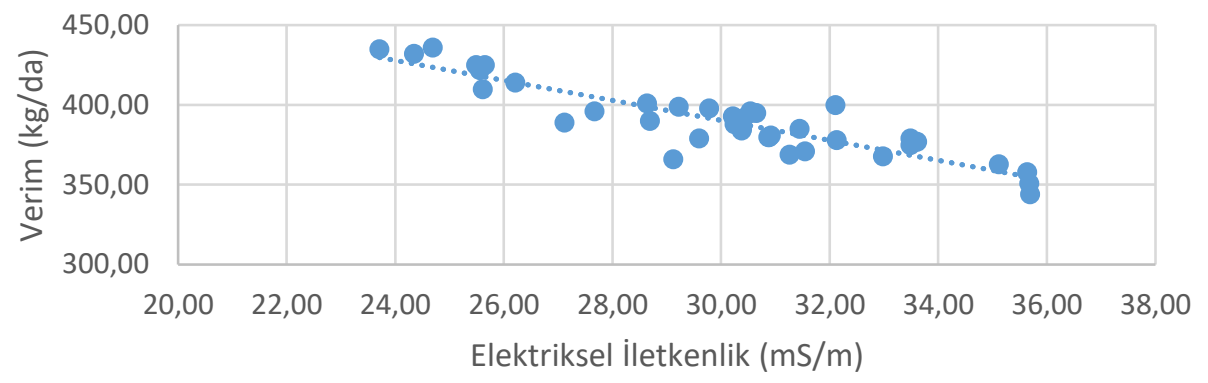

Şekil 8. Gün-91 çeşidinin elektriksel iletkenlik ile verim değerleri arasındaki ilişki

Figure 8. The relationship between electrical conductivity and yield values of Gün-91 variety

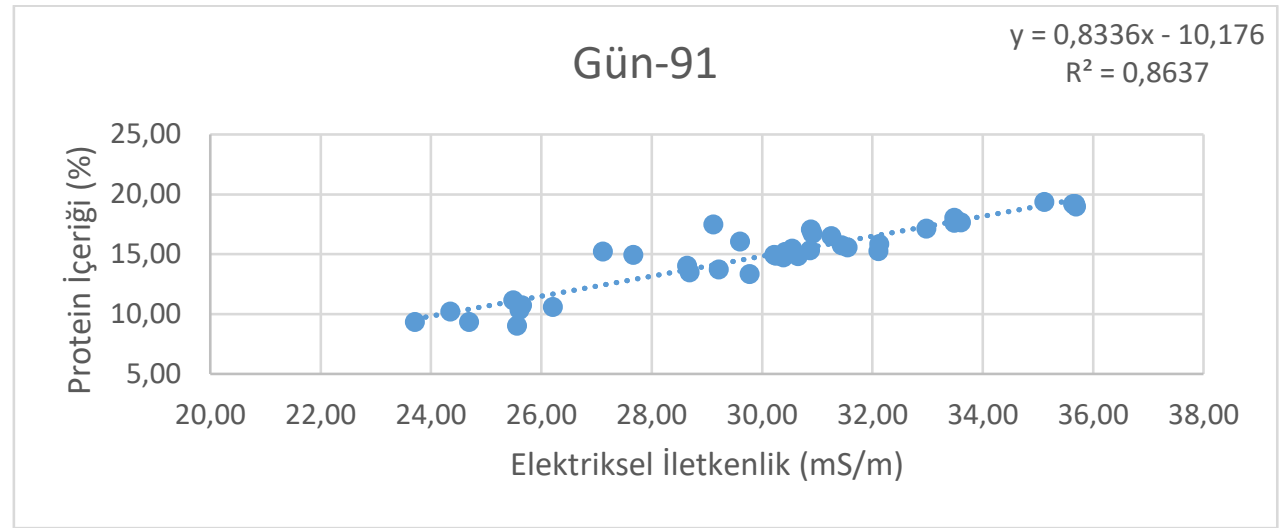

Şekil 9. Gün-91 çeşidinin elektriksel iletkenlik değerleri ile protein içeriği arasındaki ilişki

Figure 9. The relationship between electrical conductivity values and protein content of Gün-91 variety

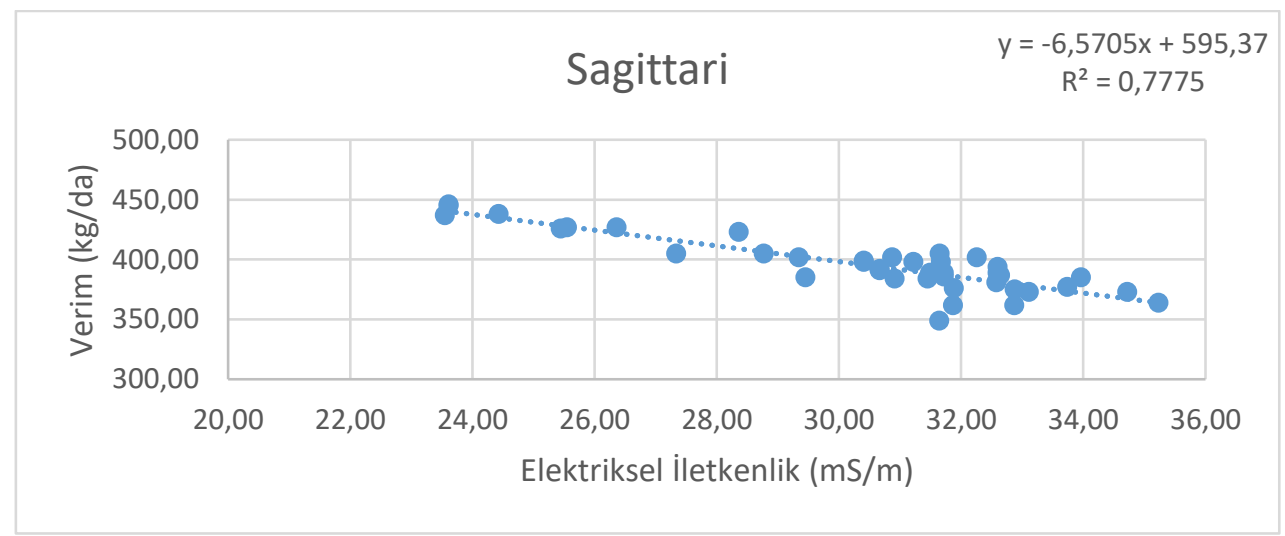

Şekil 10. Sagittari çeşidinin elektriksel iletkenlik ile verim değerleri arasındaki ilişki

Figure 10. The relationship between electrical conductivity and yield values of Sagittari variety 

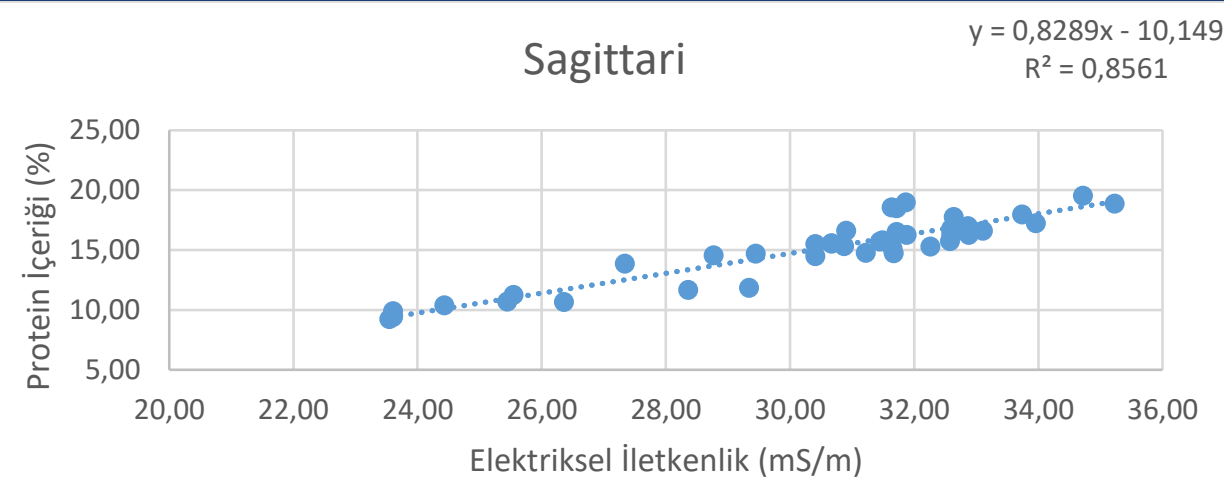

Şekil 11. Sagittari çeşidinin elektriksel iletkenlik değerleri ile protein içeriği arasındaki iliş̧i

Figure 11. The relationship between electrical conductivity values and protein content of Sagittari variety

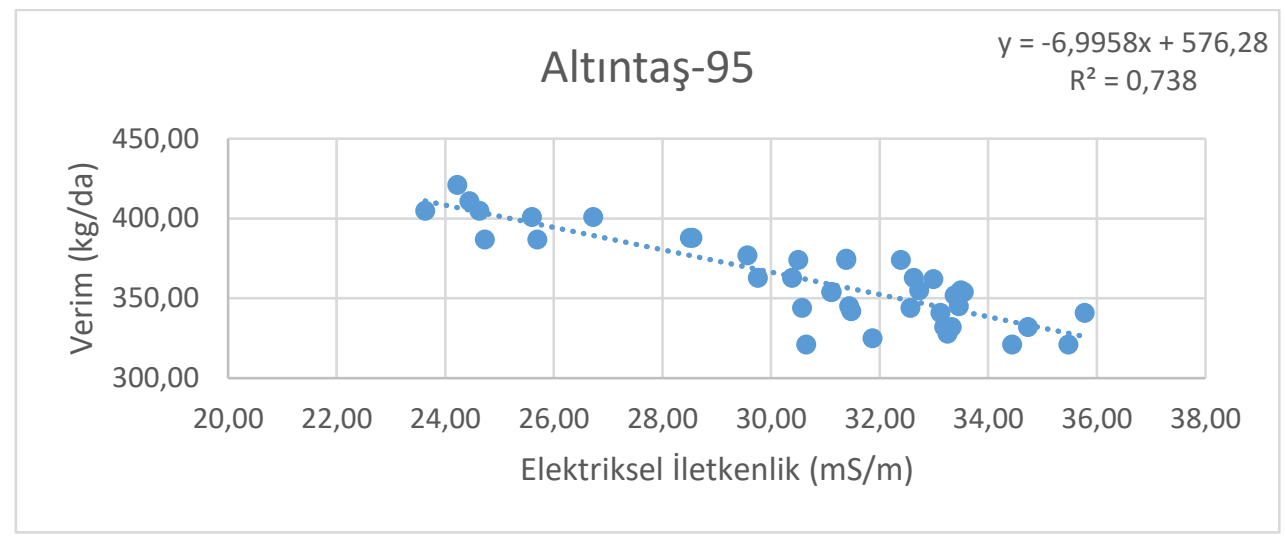

Şekil 12. Altıntaş-95 çeşidinin elektriksel iletkenlik ile verim değerleri arasındaki ilişsi

Figure 12. The relationship between electrical conductivity and yield values of Altıntaş-95 variety

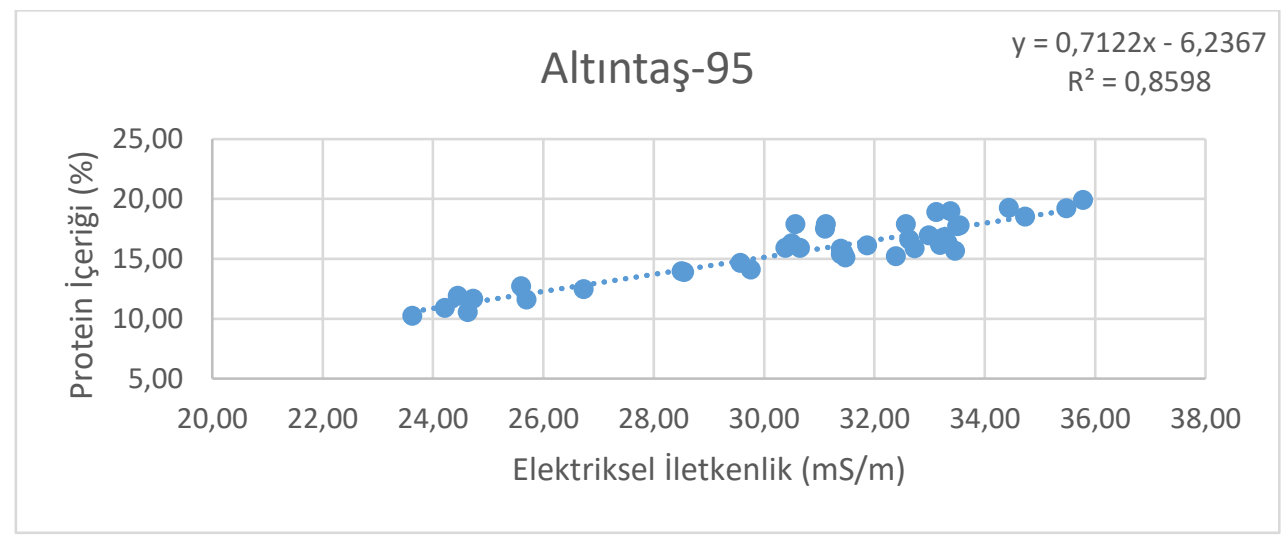

Şekil 13. Altıntaş-95 çeşidinin elektriksel iletkenlik değerleri ile protein içeriği arasındaki ilişki

Figure 13. The relationship between electrical conductivity values and protein content of Altıntaş-95 variety 


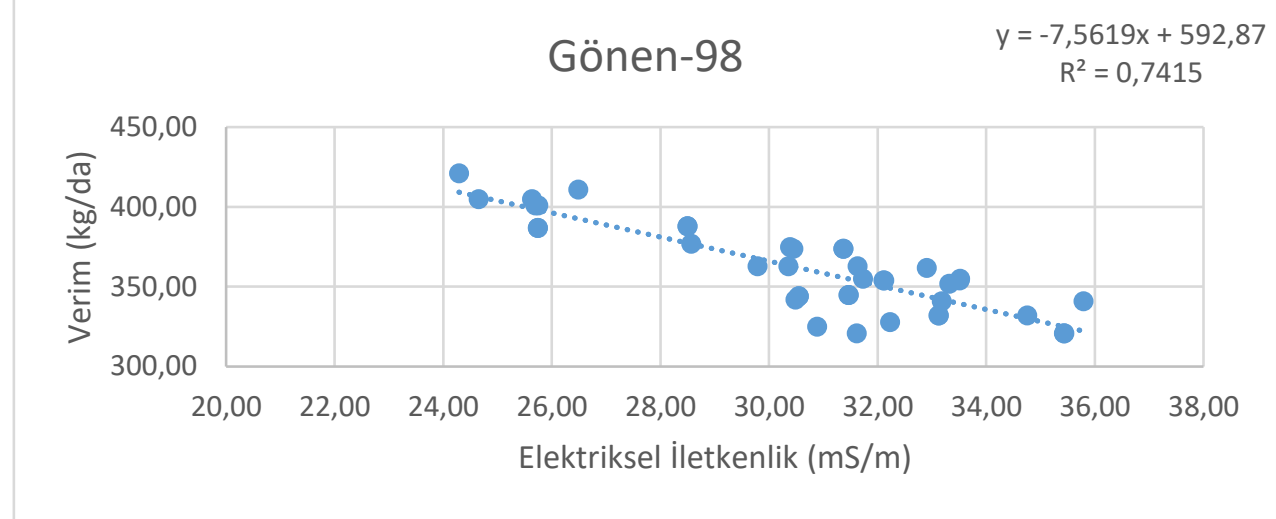

Şekil 14. Gönen-98 çeşidinin elektriksel iletkenlik ile verim değerleri arasındaki ilişki

Figure 14. The relationship between electrical conductivity and yield values of Gönen-98 variety

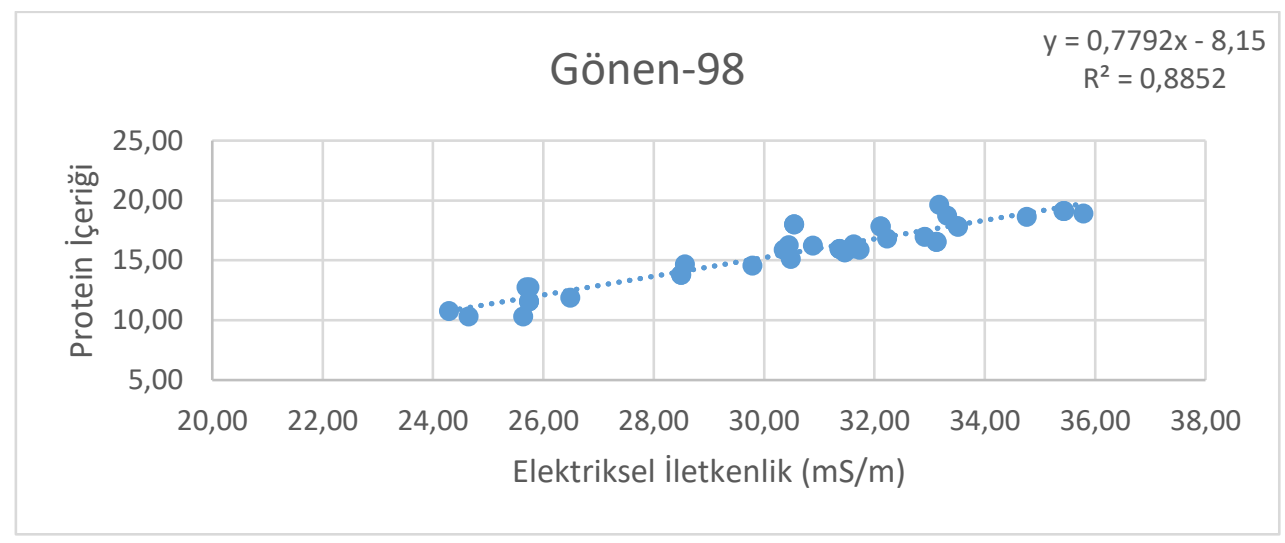

Şekil 15. Gönen çeşidinin elektriksel iletkenlik değerleri ile protein içeriği arasındaki ilişki

Figure 15. The relationship between electrical conductivity values and protein content of Gönen-98 variety

Daha önce yapılan benzer çalışmalarda olduğu gibi elde edilen sonuçlara göre toprağın elektriksel iletkenliği ve verim değerleri arasında ters bir ilişki olduğu görülmektedir. Araştırmada kullanılan 5 farklı çeşitte de arazinin elektriksel iletkenlik değerlerinin yüksek olduğu parsellerde verim değerlerinin düştüğü tespit edilmiştir. Yine ürün protein içeriği ile elektriksel iletkenlik değerleri karşılaştırıldığında doğrusal bir ilişki olduğu ve arazinin elektriksel iletkenlik değerlerinin artmasına bağlı olarak ürünün protein içeriğinin arttığı tespit edilmiştir. Buğdayda verim ve protein içeriği konusunda yapılan çalışmalarda buna benzer sonuçlar bulunmuş ve aşağıda verilmiştir. Ürünün verim değerleri arttıkça protein oranı düşmekte ve benzer şekilde ürünün verim değerleri düştükçe protein içeriğinin arttı̆̆ belirtilmiştir.

Son yıllarda domates üzerine yürütülen çalışmaların çoğu, verim ve kalitenin arttırılması ve stres faktörlerinin etkilerini azaltma üzerine yoğunlaşmıştır. $\mathrm{Bu}$ amaçla, domates yetiştiriciliğinde alternatif metotlar ve yeni teknikler sürekli olarak incelenmektedir (Geboloğlu ve ark. 2011). Aş11ı bitkilerin, toprak kökenli hastalık ve zararlılara, düşük sıcaklığa, düşük su kalitesine, kuraklığa ve aşırı 1slak topraklara dayanıklılık gibi özellikleri nedeniyle biyotik ve abiyotik stres şartlarına karşı kullanımı son yıllarda artış göstermektedir. Bu nedenle yapılan çalışmalarda arazinin elektriksel iletkenliği ölçülmekte ve haritalandırılarak yoğun bir şekilde kullanılmaktadır. 
Yegül \& Eminoğlu \& Türker Buğdayın Verim ve Kalite Parametrelerinin Toprağın Elektriksel İletkenliği ile İlişkisinin Belirlenmesi

Çizelge 2. Buğday çeşitlerinin parsellere göre elektriksel iletkenlik değerleri ile verim değerleri arasındaki ilişki

Table 2. The relationship between the electrical conductivity values and yield values according to plots for wheat varieties

\begin{tabular}{|c|c|c|c|}
\hline Tohum çeşidi & Tekerrür & Regresyon eşitliği & $\mathbf{R}^{2}$ \\
\hline Bezostaja-1 & 1 & $y=-5,4288 x+544,54$ & 0,8305 \\
\hline Bezostaja-1 & 2 & $y=-7,9419 x+626,75$ & 0,849 \\
\hline Bezostaja-1 & 3 & $y=-6,0205 x+566,72$ & 0,862 \\
\hline Bezostaja-1 & 4 & $y=-6,9874 x+592,62$ & 0,8359 \\
\hline Gün-91 & 1 & $y=-6,1875 x+568,84$ & 0,8244 \\
\hline Gün-91 & 2 & $y=-5,8672 x+569,37$ & 0,8724 \\
\hline Gün-91 & 3 & $y=-6,8794 x+597,71$ & 0,8525 \\
\hline Gün-91 & 4 & $y=-6,0486 x+574,76$ & 0,8319 \\
\hline Sagittari & 1 & $y=-7,2848 x+612,48$ & 0,7706 \\
\hline Sagittari & 2 & $y=-7,7048 x+628,35$ & 0,7994 \\
\hline Sagittari & 3 & $y=-9,0213 x+683,29$ & 0,7529 \\
\hline Sagittari & 4 & $y=-7,4359 x+618,77$ & 0,8644 \\
\hline Altıntaş-95 & 1 & $y=-7,7208 x+595,78$ & 0,8587 \\
\hline Altıntaş-95 & 2 & $y=-5,6668 x+542,17$ & 0,7375 \\
\hline Altıntaş-95 & 3 & $y=-8,4802 x+616,2$ & 0,7244 \\
\hline Altıntaş-95 & 4 & $y=-6,8754 x+571,22$ & 0,8125 \\
\hline Gönen-98 & 1 & $y=-8,0355 x+605,87$ & 0,8577 \\
\hline Gönen-98 & 2 & $y=-5,1866 x+524,92$ & 0,7626 \\
\hline Gönen-98 & 3 & $y=-9,6247 x+650,34$ & 0,7062 \\
\hline Gönen-98 & 4 & $y=-7,7286 x+595,95$ & 0,8615 \\
\hline
\end{tabular}

Çizelge 3. Buğday çeşitlerinin parsellere göre elektriksel iletkenlik değerleri ile protein içerikleri arasındaki ilişki

Table 3. The relationship between the electrical conductivity values and protein contents according to plots for wheat varieties

\begin{tabular}{|c|c|c|c|}
\hline Tohum çeşidi & Tekerrür & Regresyon eşitliği & $\mathbf{R}^{2}$ \\
\hline Bezostaja-1 & 1 & $y=0,8074 x-9,3268$ & 0,8853 \\
\hline Bezostaja-1 & 2 & $y=1,1722 x-21,099$ & 0,878 \\
\hline Bezostaja-1 & 3 & $y=0,8152 x-9,7856$ & 0,8481 \\
\hline Bezostaja-1 & 4 & $y=0,856 x-10,586$ & 0,8549 \\
\hline Gün-91 & 1 & $y=0,9082 x-12,6$ & 0,8099 \\
\hline Gün-91 & 2 & $y=0,9078 x-12,309$ & 0,9309 \\
\hline Gün-91 & 3 & $y=0,819 x-9,7098$ & 0,8452 \\
\hline Gün-91 & 4 & $y=0,7291 x-6,9758$ & 0,9119 \\
\hline Sagittari & 1 & $y=0,8596 x-10,811$ & 0,8596 \\
\hline Sagittari & 2 & $y=0,8482 x-11,066$ & 0,8543 \\
\hline Sagittari & 3 & $y=1,03 x-17,12$ & 0,7856 \\
\hline Sagittari & 4 & $y=0,9005 x-11,849$ & 0,8247 \\
\hline Altıntaş-95 & 1 & $y=0,7103 x-6,1059$ & 0,7907 \\
\hline Altıntaş-95 & 2 & $y=0,7798 x-8,1322$ & 0,738 \\
\hline Altıntaş-95 & 3 & $y=0,6557 x-4,7802$ & 0,9507 \\
\hline Altıntaş-95 & 4 & $y=0,7036 x-6,0786$ & 0,8752 \\
\hline Gönen-98 & 1 & $\mathrm{y}=0,7901 \mathrm{x}-8,5212$ & 0,8523 \\
\hline Gönen-98 & 2 & $y=0,6778 x-4,6693$ & 0,7351 \\
\hline Gönen-98 & 3 & $\mathrm{y}=0,7804 x-8,3889$ & 0,9786 \\
\hline Gönen-98 & 4 & $y=0,7686 x-7,8033$ & 0,8756 \\
\hline
\end{tabular}

Pennsylvania, Amerika Birleşik Devletlerinde gerçekleştirilen bir çalışmadaki amaç alana özgü tarımsal faaliyetler ile toprak özellikleri arasındaki ilişkilerdir. Soya fasülyesi ve mısır bitkilerinin verim değerlerinin toprak özellikleri arasındaki ilişkisi incelenmiştir. Elektromanyetik tetkikleme yöntemi (EMI) yardımı ile alınan değerler sonucunda oluşturulan haritalar ile verim değerleri arasında önemli ilişsiler bulunmuş ancak bu konuda 
JOTAF/ Journal of Tekirdag Agricultural Faculty, 2019, 16(3)

çalışmaların devam etmesi gerektiği sonucu ortaya çıkmıştır (Zhu ve ark. 2013).

Avusturalya'da yapılan üç yıllık bir çalışmada bitki olarak buğday ve arpa seçilmiş ve toprağın elektriksel iletkenliği ile ürün verimi arasındaki ilişki araştırılmış ve en düşük ürün verimi toprak elektriksel iletkenlik değerinin en yüksek olduğu koşullarda elde edilmiştir. Elde edilen değer 1,1 ton ha ${ }^{-1}$ olarak bulunmuştur (Setter ve ark. 2016).

\section{Sonuç}

Günümüzde tarımda teknoloji kullanımı en üst seviyededir. Bunun yanında teknoloji üretmek ve bunu doğru ve verimli bir şekilde kullanma zorunluluğu da ortaya çıkmıştır. Bitkilerin büyüme indekslerini tespit eden çok sayıda sensör günümüzde kullanılmaktadır. Amaç, bitkinin verim ve çeşitli kalite parametrelerini kontrol edebilmektir. Bitki büyüme indeksini tespit eden cihazların halihazırda fiyatlarının yüksek olması ve kullanımının kullanıcı dostu olmaması sebebiyle elektriksel iletkenlik ölçüm yöntemi kullanılarak her bitki için arazi koşulları iyileştirilebilir. Bu çalışma sonucunda elde edilen veriler incelendiğinde arazinin elektriksel iletkenlik değerlerinin bitkinin direk olarak verim ve kalite parametrelerine etki ettiği tespit edilmiştir. Bu durumda elektriksel iletkenlik ölçüm cihazları veya sensörleri de kullanılarak bitkinin verim ve protein içeriği gibi bazı kalite parametreleri kontrol edilebilir ve iyileştirilebilir. 


\section{Kaynakça}

Anonymous, 2019a. Geonics Limited (http://www.geonics.com/). Erişim tarihi: 29.03.2019

Anonymous, 2019b. Juniper Systems Inc. (http://www.junipersys.com/). Erişim tarihi: 29.03.2019

Anonymous, 2019c. Geomaticsgroup (http://www.geomaticsgroup.com/). Erişim tarihi: 29.03.2019

Anonymous, 2019d. Perten Instruments (https://www.perten.com/tr/). Erişim tarihi: 29.03.2019

Amor FM, Martinez V, Cerda A, 2001. Salt tolerance of tomato plants as affected by stage of plant development. Hortscience, 36(7): 12601263.

Ashraf M, 1994. Breeding for salinity tolerance in plants. Critical Reviews in Plant Sciences, 13(1): 17-42.

Bilgin N, Yıldız, N, 2008. Besin kültüründe yetiştirilen (Kaya F1) domates çeşidinin (Lycopersicon esculentum) artan NaCl uygulamalarına toleransı ve tuzluluk stresinin kuru madde miktarı ile bitki mineral madde içeriğine etkisi. Atatürk Üniversitesi Ziraat Fakültesi Dergisi, 39(1): $15-21$

Corwin D, \& Lesch S, 2005. Characterizing soil spatial variability with apparent soil electrical conductivity: I. Survey protocols. Computers and Electronics in Agriculture. 46: 103-133.

Eraslan F, Güneş A, İnal A, Çiçek N, Alpaslan M, 2008. Gübrelerden kaynaklanan tuzluluğun domates ve biber bitkisinde bazı fizyolojik özellikler ve mineral beslenme üzerine etkisi. 4. Ulusal Bitki Besleme ve Gübre Kongresi, 8-10 Ekim, Konya, 641-649.

Eraslan F, Elkarim AKH, Güneş A, İnal A, 2012. Effect of nutrient inducted salinity on growth, membrane permeability, nitrate reductase activity, proline content and, macronutrient concentrations of tomato grown in greenhouse. World Academy of Science, Engineering and Technology, 71: 1915-1919.

Fernandez-Garcia N, Martinez V, Carvajal M, 2004. Effect of Salinity on growth, mineral composition and water relations of grafted tomato plants. Journal of Plant Nutrition and Soil Science, 167: 616-622.

Geboloğlu N, Yılmaz E, Çakmak P, Aydın M, Kasap Y, 2011. Determining of the yield, quality and nutrient content of tomatoes grafted on different rootstocks in soilless culture. Scientific Research and Essays, 6(10): 2147-2153.

Giuffrida F, Martonara M, Leonardi C, 2009. How sodium chloride concentration in the nutrient solution influences the mineral composition of tomato leaves and fruits. HortScience, 44(3): 707-711.

Gui-Guerrero JL, Rebolloso-Fuentes MM, 2009. Nutrient composition and antioxidant activity of eight tomato (Lycopersicon esculentum) varieties. Journal of Food Composition and analysis, 22: 123-129.

Gunderson V, McCall D, Bechmann IE, 2001. Comparison of major and trace element concentrations in Danish greenhouse tomatoes (Lycopersicon esculentum Cv. Aromata F1) cultivated in different sustrates. J. Agric. Food Chem., 49: 3808-3815.

Huang Y, Bie Z, He S, Hua B, Zhen A, Liu Z, 2010. Imoroving cucumber tolerance to major nutrient induced salinity by grafting onto Cucurbita ficifolia. Enviromental and Experimental Botany, 69: 32-38.

Mohammed SMT, Humidan M, Boras M, Abdalla OA, 2009. Effect of grafting tomato on different rootstocks on growth and productivity under glasshouse conditions. Asian Journal of Agricultural Research, 3(2): 47-54.

Premuzic Z, Bargiela M, Garcia A, Rendina A, Loria A, 1998. Calcium, iron, potassium, and vitamin C content of organic and hyroponic tomatoes. Hort.Science 33(2): 255-257.

Rhoades JD, Chanduvi F, Lesch S, 1999. Soil salinity assessment. Methods and interpretation of electrical conductivity measurements. FAO Irrigation and Drainage Paper No. 57, Rome.

Shannon MC, 1978. Testing Salt Tolerance Variability Among Tall Wheatgrass Lines. Agronomy Journal, 70(5): 719-722.

Setter TL, Waters I, Stefanova K, Munns R, Barrett-Lennard EG, 2016. Salt tolerance, date of flowering and rain affect the productivity of wheat and barley on rainfed saline land, Field Crops Research, (194): 31-42.

Tuna AL, Kaya C, Ashraf M, Altunlu H, Yokas I, Yagmur B. 2007. The effects of calcium sulphate on growth, membrane stability and nutrient uptake of tomato plants grown under salt stres. Enviromental and Experimental Botany, 59: 173-178.

Zadoks JC, Chang TT, Konzak CF, 1974. A decimal code for the growth stage of cereals. Weed Res. 14: 415-421.

Zhu J, Bie Z, Huang Y, Han X, 2008. Effects of grafting on the growth and ion concentrations of cucumber seedlings under NaCl stres. Soil Science and Plant Nutrition, 54: 895-902.

Zhu Q, Lin HS, Doolittle JA, 2013. Functional soil mapping for site-specific soil moisture and crop yield management, Geoderma, (200-201): 45-54. 
